\title{
Editors' Preface
}

"At the beginning kings ruled the city of Rome." Brutus established the free Republic; its working was interrupted in emergencies and times of civil strife by dictatorships and other forms of autocratic rule. Pompey's and Crassus' predominance was overturned by Caesar, that of Antony and Lepidus by Augustus. "He found the whole state exhausted by civic dissensions and took it under his imperium, using the name of princeps" (urbem Romam a principio reges habuere ... [Augustus] cuncta ... nomine principis sub imperium accepit). So Tacitus at the beginning of his Annals (1.1). The cycle, that is, was closed; Rome once again was ruled by a monarchy.

Augustus, Tacitus continues, seduced the army with gifts, the people with cheap grain, everybody with the sweetness of peace. Gradually, he took over the functions of the senate, the magistrates, even the law. Nobody resisted; the fiercest spirits had been eliminated in wars and proscriptions, the other nobles tamed by the prospect of wealth, honor, and security in direct reciprocity to servile subordination. And to the provinces the new order guaranteed an end of the suffering caused by fighting potentates and corrupt magistrates (1.2).

This, in a nutshell, is Tacitus' conception of the nature and success of 
Augustus' principate. "Probably nothing more malicious has ever been written than the description of the last years of Augustus and the survey of his achievements in the opening of the Annals," said the great Eduard Meyer in 1903 in an address to the Association of German Historians, and he continued:

It is particularly perfidious that Tacitus replaces the funeral oration contained in his sources with a report of the sermones de Augusto (1.9f. [the debate about Augustus supposedly waged in Rome after his death]) which, while appearing to be quite objective, in fact creates and intends to create the impression that the worst and most absurd accusations represented historical truth. ${ }^{1}$

Perfidious or not, in those sermones Tacitus in fact sharply and lucidly defined the two positions between which the "debate about Augustus" has been waged ever since.

Almost by necessity, those who judge the first princeps favorably distinguish between Octavian, the avenger, proscriber, military adventurer, and civil war general, and Augustus, the princeps and creator of the res publica restituta, benevolent leader of Rome, Italy, and the reunited empire, bringer of peace, reformer, and organizer. For this concept, a break and new beginning in the years 30-27 is almost indispensable. The achievements and blessings of the principate are perceived as more than mere atonement for the brutal shortcomings and crimes of the civil war period. Velleius Paterculus, often maligned as "court historian" and spineless flatterer but the only contemporary among the extant historians, is the first to endorse this view, with much support from the poets.

By contrast, the opposing, negative view of the Augustan principate is "unitarian": there was no break, no new beginning, no transformation. Octavian and Augustus were the same, logical and consequent from beginning to end, ruthlessly pursuing but one end: power. Character and goals did not change, whatever the methods and façades chosen to disguise the realities.

Admittedly, these are the two extreme positions, but there is no doubt that Tacitus preferred the latter. Under his influence and praise of the libera res publica this is the sermo that prevailed, with few exceptions, until the middle of the nineteenth century. Montesquieu's verdict on the rusé tyran (the cunning tyrant) was echoed in Gibbon's "subtle tyrant," 2

1. E. Meyer, "Kaiser Augustus," HZ 91 (1903) 385-431 (= id., Kleine Schriften², vol. 1 [Halle 1924] 423-74); editors' translation. VIIIf.

2. Cf. W. Schmitthenner, ed., Augustus, Wege der Forschung 128 (Darmstadt 1969) 
and resounded again, more than 150 years after Gibbon, in Sir Ronald Syme's Roman Revolution, for which Tacitus served as one of the crown witnesses.

Theodor Mommsen, il grande Teodoro, as he was sometimes called in Italy, ${ }^{3}$ in his Staatsrecht defined the principate as a magistracy and the Augustan order as a "dyarchy" 4 in which power and responsibilities were fairly evenly divided and a large amount of cooperation was realized between senate and princeps. The republican element thus was emphasized, and scholarship, particularly in Germany, with its predilection for the history of law, was set on a predominantly legalistic track. Mommsen himself slightly modified his views in later publications, and reaction against these views was strong already among his contemporaries. ${ }^{5}$ Still it took two generations to dismantle the dyarchic model, which was fully accepted by, among others, Victor Gardthausen and Eduard Meyer. Its last remains were buried, together with the predominance of the legalistic approach, by Syme's Roman Revolution. ${ }^{6}$

The first truly comprehensive biography of Augustus and analysis of his time was published almost one hundred years ago, between 1891 and 1904, by Victor Gardthausen. ${ }^{7}$ On its level of detailed discussion and thorough documentation it has, so far, found no successor. The great figures of the period, Augustus' forerunners, contemporaries, and successors, have all received their comprehensive biographical tribute in recent decades; Augustus has not. Certainly there have been many biographical sketches, ${ }^{8}$ and a few years ago the results of previous scholarship and the state of our knowledge were summed up in a learned and useful book by Dietmar Kienast. ${ }^{9}$ But there is no comprehensive, penetrating, modern analysis of Augustus, the man, his work, and his time. ${ }^{10}$

This gap in scholarship, instructive in itself, has several explanations, among them the sheer mass of scholarship published annually on dozens of hotly debated questions, the problems caused by the very difficult

3. E. Kornemann, Augustus: Der Mann und sein Werk (im Lichte der deutschen Forschung), Breslauer histor. Forsch. 4 (Breslau 1937) 1.

4. T. Mommsen, Römisches Staatsrecht ${ }^{3}$, vol. 2. (Leipzig 1888).

5. T. Mommsen, Abriss des römischen Staatsrechts (Leipzig 1893) 340-45; J. Kromayer, Die rechtliche Begrïndung des Principats (Marburg 1888).

6. But see now J. Linderski in his contribution to the present volume.

7. V. Gardthausen, Augustus und seine Zeit, 2 vols. in 6 parts (Leipzig 1891-1904; bibliography added 1917; reprint with new bibliography, Aalen 1964).

8. One of the best by A. H. M. Jones, Augustus (London 1970).

9. D. Kienast, Augustus: Prinzeps und Monarch (Darmstadt 1982).

10. Pace M. A. Levi, Augusto e il suo tempo (Milan 1986), which represents a revised and rethought combination of two earlier books: Ottaviano capoparte (Florence 1933) and Il tempo di Augusto (Florence 1951). 
source situation, and the constant flow of new evidence, mostly epigraphical and archaeological, from excavations all over the empire. The sculptures of the sebasteion and inscriptions of the theater in Aphrodisias in Asia Minor and the giant solarium (sundial) of Augustus on the Campus Martius in Rome are only two spectacular recent examples of the latter. ${ }^{11}$ Furthermore, whoever attempts a new comprehensive treatment of Augustus and his time must come to terms with Syme's Roman Revolution. Although beginning with the year 60 (and thus neither with the year of Augustus' birth nor with that of his entry into politics) and emphatically disclaiming to be a biography of Augustus or a study of his career and principate, ${ }^{12}$ Syme's book is nevertheless all that and more: it contains many elements of a biography of the individual named Caesar Augustus and, collectively, of the Roman upper class in his lifetime, and "it is also a general interpretation of the Augustan principate." ${ }^{13}$ In view of all these obstacles the most enterprising scholar might well be deterred by the formidable task of writing a new "Gardthausen."

Gardthausen himself had been fairly critical of Augustus. Eduard Meyer in turn strongly defended the positive, "Republican" view. ${ }^{14}$ The pendulum kept swinging for a while: as late as 1933 Meyer's assessment was endorsed vigorously by Mason Hammond..$^{15}$ But in the 1930s, when the bimillennium of Augustus' birth was approaching and being celebrated with lavish exhibitions and congresses and sensational excavations (of the Forum of Augustus, his mausoleum, and the Ara Pacis, among others), the pendulum swung far beyond the limits of sound scholarly debate: Augustus became the idealized figurehead and patron of another novus status, Mussolini's new Roman Empire. ${ }^{16}$

It was against such uncritical glorification of Augustus and under the impression both of the seemingly unstoppable success of the Continen-

11. Sebasteion: K. T. Erim, Aphrodisias: City of Venus Aphrodite (London 1986). Inscriptions: J. Reynolds, Aphrodisias and Rome: Documents from the Excavation of the Theatre at Aphrodisias, JRS Mon. 1 (1982). Solarium Augusti: E. Buchner, Die Sonnenubr des Augustus (Mainz 1982).

12. R. Syme, The Roman Revolution (Oxford 1939) vii.

13. A. Momigliano, JRS 30 (1940) 77 (review of Syme's Roman Revolution), reprinted in id., Secondo contributo alla storia degli studi classici e del mondo antico (Rome 1960) 410.

14. Cf. H. E. Stier, “Augustusfriede und römische Klassik," ANRW 2.2 (1975) 3f.

15. M. Hammond, The Augustan Principate in Theory and Practice during the JulioClaudian Period (Cambridge, Mass. 1933).

16. Cf. K. Hönn, Augustus im Wandel zweier Jahrtausende (Leipzig 1938) 46; K. Christ, "Zur Beurteilung der Politik des Augustus," GWU 19 (1968) 336f.; A. Momigliano, Terzo contributo alla storia degli studi classici e del mondo antico (Rome 1966) 732. 
tal dictators and of the publication of the new constitution of the Soviet Union that Ronald Syme wrote his first major book. ${ }^{17}$ The Roman Revolution was immediately hailed as the best book on Roman history since Mommsen, Rostovtzeff or Eduard Meyer: ${ }^{18}$ "a work of art unmatched among major historical works, and one which would still be read as such even if the day were to come when our knowledge of Roman history has been transformed by new evidence, or when we have found wholly new means of interpreting it." 19 The achievement was most impressive indeed, the glory well deserved. With his subsequent books ${ }^{20}$ and a host of articles collected in several volumes, ${ }^{21}$ Syme went on to become the "Emperor of Roman History," 22 that title, too, well deserved. On the occasion of the publication of the first two volumes of the Roman Papers in 1979 and of Syme's eightieth birthday in 1983, his achievement was acknowledged and discussed by several scholars. ${ }^{23}$

Despite the high acclaim it immediately won among those who had the opportunity to read it, "The Roman Revolution had to wait a long time for widespread recognition. The Second World War effectively kept the book from entering the mainstream of historical scholarship, and it was not until the early 1950's that Syme's impact began to be felt. But the impact, when it finally came, was tremendous." ${ }^{24}$ For its healthy reaction to the traditional and often abused benevolent assessment of Augustus, for its intellectual honesty, for its methodology, immense prosopographical knowledge, and total control of sources and facts, for its sensitivity toward literature, and for its brilliant "Tacitean" style the book proved and remained irresistible. ${ }^{25}$ For fifty years now it has been

17. Cf. G. Alföldy, Sir Ronald Syme, "Die römische Revolution" und die deutsche Althistorie, SBHeid 1983, no. 1, 21; F. Millar, "Style Abides," JRS 71 (1981) 146; Momigliano (supra n. 16) 730 .

18. G. Bowersock, "The Emperor of Roman History," The New York Review of Books, 6 March 1980, 8.

19. Millar (supra n. 17) 146; cf. D. R. Shackleton Bailey, "The Roman Nobility in the Second Civil War," CQ n. s. 10 (1960) 266, n. 3: "No desert island would be desirable without that dazzling, venerable, wise, and sometimes exasperating classic, The Roman Revolution"; both quoted by Alföldy (supra n. 17) 5 .

20. Tacitus, 2 vols. (Oxford 1958); Sallust (Berkeley and Los Angeles 1964); Ammianus Marcellinus and the Historia Augusta (Oxford 1968); Emperors and Biography: Studies in the Historia Augusta (Oxford 1971); The Historia Augusta: A Call for Clarity (Bonn 1971); History in Ovid (Oxford 1978); The Augustan Aristocracy (Oxford 1986).

21. Ten Studies in Tacitus (Oxford 1970); Danubian Papers (Bucharest 1971); Roman Papers, vols. 1 and 2 (Oxford 1979), vol. 3 (1984), vol. 4 (1987), vol. 5 (1988).

22. Bowersock (supra n. 18).

23. Alföldy, Millar, Bowersock (supra nn. 17 and 18).

24. Bowersock (supra n. 18).

25. Cf. Momigliano's comment on the book's "intrinsic value" (1940: supra n. 13) 75 (= 1960 [supra n. 13] 407): "the enormous, unpedantic store of information; the per- 
the standard work on the transition from republic to principate, on the dramatic changes in the aristocracy of that period-and on Augustus.

Certainly, The Roman Revolution has its faults and weaknesses too; they have been pointed out in reviews and occasional critical essays. ${ }^{26}$ In many ways it is, as it wants to be, ${ }^{27}$ a disturbing book. Not only is it deliberately critical of Augustus, it attempts "to record the story of the Roman Revolution and its sequel, the Principate of Caesar Augustus, in a fashion that has now become unconventional, from the Republican and Antonian side." ${ }^{28}$ Thus it accepts the position taken by Sallust, the elusive Pollio, and Tacitus and the social and political point of view of the "doomed nobility" with its limitations and prejudices. It focuses on the organization of power, the composition of factions and "parties," and thus on Augustus, the Machtpolitiker. It therefore does not treat equally extensively all areas of Augustus' activity. Yet it still passes judgment, implicitly and explicitly, on Augustus the princeps and his achievement. Indeed, political success does not have to be praised or idealized. But Syme's claim that Augustus' "ability and greatness will all the more sharply be revealed by unfriendly presentation" ${ }^{29}$ remains largely unfulfilled-unless the ability to reach and maintain power serves as the main criterion for greatness. Tacitus, some will feel, is no reliable guide to the Augustan principate, and the libertas that, according to Syme (and Tacitus), was slaughtered at Pharsalus, Philippi, and Actium and received its definitive funeral in A.D. 14 meant little or nothing to the overwhelming majority of Augustus' contemporaries.

Every scholar is entitled to his own method and bias. The issue is not to return to a "favorable" or "benevolent" assessment of Augustus, but rather to arrive at a balanced view. One would expect that a book with such a pointed thesis, conscious and admitted bias, and, in essential ways, limited approach to the analysis and reconstruction of history should have become, despite its numerous merits and outstanding qualities, the focus of intensive scholarly debate. This did happen in some specific areas-concerning Syme's concept of faction and "party" (in

sonal method of combining particulars just at the point at which a general construction is possible; the gusto in describing men and situations; and, above all, the vigorous power of working out from a trite subject a new image full of life and revealing a consciousness of values more profound than the simple acceptance of life itself."

26. Cf. esp. A. Momigliano, JRS 30 (1940) 75-80 (= id. 1960 [supra n. 13] 407-16); A. F. Giles, CR 54 (1940) 38-41; and H. Galsterer's contribution to the present volume. Stier (supra n. 14) 3-54 overstates his case.

27. Syme (supra n. 12) viii; cf. Giles (supra n. 26) 39.

28. Syme (supra n. 12) 6 f.

29. Ibid., 7. 
connection with the possibilities and limitations of prosopography), for example, and his use of the term revolution. ${ }^{30}$ Otherwise, attempts to enter a direct, serious, and productive Auseinandersetzung with Syme's assessments and particularly his view of the nature and achievement of Augustus' principate have been rare and, at least in one recent case, hampered by emotion and polemics. ${ }^{31}$ Why this is so cannot be discussed here; suffice it to state the case: Syme's achievement is unquestionably monumental, but his Augustus and the principate created by Augustus remain in need of reassessment.

Yet such reassessment has been going on, on a small scale, ever since The Roman Revolution was published. As Zvi Yavetz points out, many of the gaps left open by Syme have been filled. ${ }^{32}$ Alternative interpretations have been offered-by Christian Meier, for example, on the crisis of the Republic, on the achievement and failure of Julius Caesar, and on Augustus' rise and success. ${ }^{33}$ And in the scholarly contributions of a great number of specialists in various disciplines who keep analyzing and reanalyzing old and new evidence the reassessment is being carried on every day. To give just a few examples: $:^{34}$ what can be known about Pollio's history has been thoroughly discussed by B. Haller, and, thanks to A. J. Woodman, we now understand better the nature of Velleius Paterculus' work; nor have the other historians been neglected. ${ }^{35}$ Augustus' relationship to the people of Rome and their ways of expressing their sentiments have been explored by Z. Yavetz, R. Gilbert, H. Kloft, and T. Bollinger; the "taming" of the civil war armies and the soldiers'

30. For a brief discussion, see Bowersock (supra n. 18) 8-10; Alföldy (supra n. 17) 8ff.; and Galsterer in the present volume.

31. Stier (supra n. 14) 3-54.

32. Z. Yavetz, in the opening section of his contribution to this volume, with examples in his notes; cf. K. Galinsky, "Recent Trends in the Interpretation of the Augustan Age," The Augustan Age 5 (1986) 22-36; see also the titles listed in the following notes.

33. C. Meier, Res publica amissa (Wiesbaden 1966; 2nd ed., Frankfurt 1980); id., Caesar (Berlin 1982); id., "Augustus: Die Begründung der Monarchie als Wiederherstellung der Republik," in id., Die Ohnmacht des allmächtigen Dictators Caesar: Drei biographische Skizzen (Frankfurt 1980) 223-87; cf. Meier's contribution to the present volume.

34. For recent bibliographies, see B. Haller, "Augustus und seine Politik: Ausgewählte Bibliographie," ANRW 2.2 (1975) 55-74; Kienast (supra n. 9) 431-52.

35. B. Haller, C. Asinius Pollio als Politiker und zeitkritischer Historiker: Ein Beitrag zur Geschichte des Übergangs von der Republik zum Prinzipat in Rom, 60-30 v.Chr. (Diss. Münster 1967); A. J. Woodman, Velleius Paterculus: The Tiberian Narrative: $2.94-$ 131, Cambr. Class. Texts and Comm. 19 (Cambridge 1977). Much useful work has been done on Cassius Dio: F. Millar, A Study of Cassius Dio (Oxford 1964); B. Manuwald, Cassius Dio und Augustus: Philologische Untersuchungen zu den Büchern 45-46 des dionischen Geschichtswerkes, Palingenesia 14 (Wiesbaden 1979); M. Reinhold, From Republic to Principate: An Historical Commentary on Cassius Dio's Roman History Books 49-52 (36-29 B.C.), Amer. Philol. Assoc. Mon. Ser. 34 (Atlanta 1988). 
role in the new system are the subject of recent studies by B. Campbell and K. Raaflaub, while F. Vittinghoff and L. Keppie have discussed the wide range of civil and military colonization under Augustus. ${ }^{36}$ Augustus' policy toward the Greek East was analyzed by G. W. Bowersock, that toward the Parthians by K. Ziegler, and his German policy by C. Wells. ${ }^{37}$ The role of the senate as a whole and of various segments of the senatorial and equestrian elite in Augustus' scheme was examined by P. Sattler, P. A. Brunt, T. P. Wiseman, and others; the role of the princeps in jurisdiction by J. Bleicken and A. H. M. Jones, that of the consilium principis by J. Crook, while R. Szramkiewicz systematically assembled all available information about Augustus' provincial governors. ${ }^{38} \mathrm{E}$. S. Ramage and various commentators have devoted much attention to the purpose, date, and content of the Res Gestae, C. Habicht and S. R. F. Price to the beginnings of the cult of the emperor, and J. Béranger and A. Wallace-Hadrill to various aspects of the "imperial ideology." ${ }^{39} \mathrm{Fi}-$ nally, E. Simon and P. Zanker have written not only many individual

36. Z. Yavetz, Plebs and Princeps (Oxford 1969; reprint, New Brunswick, N.J. 1988); R. Gilbert, Die Beziehungen zwischen Princeps und stadtrömischer Plebs im frühen Principat (Bochum 1976); H. Kloft, Liberalitas Principis (Cologne 1970); T. Bollinger, Theatralis licentia: Die Publikumsdemonstrationen an den öffentlichen Spielen im Rom der früheren Kaiserzeit und ibre Bedeutung im politischen Leben (Winterthur 1969); cf. also P. Veyne, Le pain et le cirque (Paris 1976); J. B. Campbell, The Emperor and the Roman Army, 31 B.C.-A.D. 235 (Oxford 1984); K. Raaflaub, "Die Militärreformen des Augustus und die politische Problematik des frühen Prinzipats," in G. Binder, ed., Saeculum Augustum, vol. 1, Wege der Forschung vol. 266 (Darmstadt 1987) 246-307; F. Vittinghoff, Römische Kolonisation und Bürgerrechtspolitik unter Caesar und Augustus, AbhMainz 1951, no. 14 (Wiesbaden 1952); L. Keppie, Colonisation and Veteran Settlement in Italy, 47-14 B.C. (London 1983).

37. G. W. Bowersock, Augustus and the Greek World (Oxford 1965); K. Ziegler, Die Beziebungen zwischen Rom und dem Partherreich (Wiesbaden 1964); C. M. Wells, The German Policy of Augustus: An Examination of the Archaeological Evidence (Oxford 1972); cf. also S. L. Dyson, The Creation of the Roman Frontier (Princeton 1985).

38. P. Sattler, Augustus und der Senat: Untersuchungen zur römischen Innenpolitik zwischen 30 und 17 v.Chr. (Göttingen 1960); P. A. Brunt, "The Role of the Senate in the Augustan Regime," CQ n. s. 34 (1984) 423-44; T. P. Wiseman, New Men in the Roman Senate, 139 B.C.-14 A.D. (Oxford 1971); H. H. Pistor, Prinzeps und Patriziat in der Zeit von Augustus bis Commodus (Freiburg 1965); G. Pfister, Die Erneuerung der römischen iuventus durch Augustus (Regensburg 1976); J. Bleicken, Senatsgericht und Kaisergericht (Göttingen 1962); A. H. M. Jones, The Criminal Courts of the Roman Republic and Principate (Oxford 1972); J. Crook, Consilium Principis (Cambridge 1955); R. Szramkiewicz, Les gouverneurs de province à l'époque augustéenne: Contribution à l'histoire administrative et sociale du principat, 2 vols. (Paris 1976).

39. E. S. Ramage, The Nature and Purpose of Augustus' "Res Gestae," Historia Einzelschr. 54 (Stuttgart 1987) (with literature); C. Habicht, "Die augusteische Zeit und das erste Jahrhundert nach Christi Geburt," in O. Reverdin, ed., Le culte des souverains dans l'empire romain, Entretiens sur l'ant. class. 19 (Vandoeuvres and Geneva 1973) 39-99; S. R. F. Price, Rituals and Power: The Roman Imperial Cult in Asia Minor (Cambridge 1984); cf. also A. Wlosok, ed., Römischer Kaiserkult, Wege der Forschung 372 (Darmstadt 1978); J. Béranger, Recherches sur l'aspect idéologique du principat (Basel 1953); 
studies but also major comprehensive works on the art and archaeology of the Augustan monuments in Rome. ${ }^{40}$

Thus work has been progressing on many fronts, carried on by a great number of scholars in many countries. Reflecting the complexities and contradictions in the personality, the life and achievement, and the period of Augustus, there is as yet no single direction, no united development, in Augustan scholarship. ${ }^{41}$ Efforts to produce comprehensive summaries of the results of research in major areas (such as those by $\mathrm{E}$. Simon and P. Zanker) are rare. Despite the impressive list of recent works mentioned above (which could be continued almost ad libitum), it still is true that, in Syme's own words, "there is work to be done." 42 In fact, it might be said, the time for a comprehensive reassessment has not yet come, because among other reasons so many individual problems still await thorough treatment and better understanding.

In the master's spirit the papers united in this volume discuss both Einzelfragen and more general interpretations in various areas of $\mathrm{Au}-$ gustan studies. They provide modern and penetrating analyses of important issues on the present horizon of Augustan scholarship. By achieving a better understanding of parts of the Augustan question, they are intended to advance our understanding of the whole, thereby contributing their share to the ongoing reassessment, or rather multiple reassessments, of Augustus and his principate.

Most of the papers were presented in earlier versions at a series of colloquia held at Brown University in the spring of 1987. These were organized in conjunction with an interdisciplinary graduate seminar that analyzed the Augustan principate from the perspectives of historiography, poetry, art, religion, and politics. These approaches, representing five major categories of evidence and problems intensely dis-

id., Principatus (Geneva 1973); A. Wallace-Hadrill, “The Emperor and His Virtues," Historia 30 (1981) 298-323; id., "The Golden Age and Sin in Augustan Ideology," P \& P 95 (1982) 19-36; id., "Image and Authority in the Coinage of Augustus," JRS 76 (1986) 6687.

40. P. Zanker, Forum Romanum: die Neugestaltung durch Augustus (Tübingen 1972); id., Forum Augustum: das Bildprogramm (Tübingen 1968); id., The Power of Images in the Age of Augustus (Ann Arbor 1988 = Augustus und die Macht der Bilder [Munich 1987, transl. A. Shapiro]); E. Simon, Augustus: Kunst und Leben in Rom um die Zeitenwende (Munich 1986); see also, for example, P. Gros, Aurea templa: Recherches sur l'architecture religieuse de Rome à l'époque d'Auguste (Rome 1976).

41. Cf. Galinsky (supra n. 32) 33, who emphasizes that it is not the scholar's main task to straighten out such contradictions: "They are, in fact, essential for the dynamic tensions which kept the age of Augustus from becoming self-satisfied and stagnating."

42. Syme, Roman Papers 2:711. 
cussed in the field of Augustan studies, largely determined the selection of the participants in the colloquia. Thus the selection of topics covered in this volume is to some extent fortuitous. At the same time it is programmatic, because it gives expression to the firm belief that no valid reassessment of Augustus' principate is possible without comprehensively taking into account all categories of evidence and all aspects of life, administration, and politics. The format, content, and sources of the elogia chosen for the statues of famous triumphatores in the forum Augusti, the ambiguities in a Horatian encomium to the princeps and those in Ovid's longest poem from exile, the programmatic display of rare pieces in the aedes Concordiae Augustae dedicated at the very end of Augustus' life and the significance of pictures and symbols chosen for his coins, the emergence and function of the new college of Augustales and the social and religious role thus attributed to freedmen, and the contradictions between the martial self-representation and the pragmatic foreign policy of the new regime-all these topics and the others discussed in this volume represent important contributions to a comprehensive and balanced assessment of a complex man, system, and period. ${ }^{43}$

The abbreviations of periodicals in the footnotes follow those suggested by the American Journal of Archaeology (AJA) or, in cases not listed there, the Année philologique. Standard works are referred to as the AJA directs. Classical works and authors are abbreviated in accordance with the Oxford Classical Dictionary.

Finally, we wish to thank the Departments of Classics, History and Religious Studies, the Center for Old World Archaeology and Art, the Program in Art History and the Ancient Studies Program as well as the Lectureship Fund at Brown University for their generous support of

43. For other recent collected volumes that in many ways are complementary to this one, see F. Millar and E. Segal, eds., Caesar Augustus: Seven Aspects (Oxford 1984); T. Woodman and D. West, eds., Poetry and Politics in the Age of Augustus (Cambridge 1984); Klio 67.1 (1985), containing the papers of a conference held in Jena in 1982 on "Die Kultur der Augusteischen Zeit"; R. Winkes, ed., The Age of Augustus: Conference Held at Brown University, Providence, R.I., 1982, Archaeologia Transatlantica $S$ (Louvain-la-Neuve and Providence 1986); G. Binder, ed., Saeculum Augustum, vol. 1, Herrschaft und Gesellschaft (Darmstadt 1987), vol. 2, Religion und Literatur (1988), vol. 3, Kunst und Bildersprache (forthcoming). Although belonging to the "Wege der Forschung" series, all three Saeculum Augustum volumes contain some contributions specifically written for the occasion. 
the colloquia at which most of the papers in this volume were first read; Gregory Bucher, James Kennelly, Jonathan Robbins and, particularly, Ruthann Whitten for their invaluable assistance in preparing this volume; the anonymous referees who read the entire work or individual contributions; Marian Shotwell who painstakingly copy-edited the typescript; and Richard Holway, Mary Lamprech and other staff members of the Press whose enthusiastic and patient support was crucial for the success of this project.

It was our intention, enthusiastically shared by all contributors but as yet unknown to the honoree, to dedicate this volume to Sir Ronald himself on the occasion of the fiftieth anniversary of The Roman Revolution. On 4 September 1989, however, he passed away, only three days before that anniversary. Sadly and respectfully, we now offer this volume as a dedication to the memory of an extraordinary scholar.

-September, 1989 
